\title{
Dark materials: pre-Columbian black lithic carvings from St Vincent and the wider Caribbean
}

F. Brock ${ }^{1 \dagger}$, J. Ostapkowicz ${ }^{2}$, M.E. Collinson ${ }^{3}$, I.D. Bull ${ }^{4}$, C. Dyer ${ }^{1 *}$, D.W. Lane ${ }^{1}$,

K. Domoney ${ }^{5}$, J. Uden ${ }^{6}$.

1. Cranfield Forensic Institute, Cranfield University, Defence Academy of the United Kingdom, Shrivenham, SN6 8LA, UK.

2. School of Archaeology, University of Oxford, 36 Beaumont Street, Oxford, OX1 2PG, UK.

3. Department of Earth Sciences, Royal Holloway University of London, Egham, Surrey, TW20 0EX, UK.

4. Organic Geochemistry Unit, School of Chemistry, University of Bristol, Cantock's Close, Bristol, BS8 1TS, UK.

5. Ashmolean Museum of Art \& Archaeology, University of Oxford, Beaumont Street, Oxford, OX1 2PH, UK.

6. Pitt Rivers Museum, University of Oxford, South Parks Road, Oxford, OX1 3PP, UK.

† Corresponding author: f.brock@cranfield.ac.uk

*Present address: Renishaw plc, Spectroscopy Products Division, New Mills, Wotton-under-Edge, Glos., GL12 8JR, UK.

Keywords: Circum-Caribbean, cannel coal, lignite, carvings, pre-Columbus

\section{Highlights:}

- Analysis of material from two pre-Columbian 'black' carvings from St Vincent

- Their chemical composition and biological components are similar to cannel coal

- Material for both carvings is therefore likely to have originated in South America 
- Indicates potential social and trade networks spanning the circumCaribbean

\section{Disclaimer:}

Declarations of interest: none

\section{Abstract:}

A small number of pre-Columbian black lithic carvings are known to have been found at archaeological sites across the Caribbean, as well as in parts of neighbouring mainland South America. The identity of the material used to create these artefacts is often unknown, but suggestions include lignite, wood, petrified wood, manja(c)k, jet (or 'jet-like' materials) and hardened asphalt. These identifications are often historical and lacking any scientific basis, and as such can be unreliable. However, identification of the material has the potential to inform on the source of the carving and thereby pre-Columbian trade routes within the circum-Caribbean region. Four analytical techniques (reflectance microscopy, FTIR, Py-GC/MS, x-ray fluorescence) were applied to samples taken from two carvings found on St Vincent and five comparative materials. Both artefacts were found to be most likely to be carved from cannel coal, indicating that they originated in South American (where cannel coal is found extensively in locations in Colombia and Venezuela), as the material is not found within the Caribbean region.

\section{Introduction}

Pre-Columbian Caribbean archaeology is based overwhelmingly on ceramic and stone artefacts. Surviving wooden artefacts are rare (e.g. Ostapkowicz et al., 2012, 2013), and carvings of fossilised wood and other black organic materials are rarer still. As such, these have remained a largely unrecognised artistic medium (Ostapkowicz, 2016, Ostapkowicz, in press). These fine-grained, usually matte, black and black-brown materials have been used for a variety of carvings, ranging from small anthropo-/zoomorphic ornaments (Figure 1) to drug-related paraphernalia (Figures 2 and 3) and, based on current knowledge, have been found at a small selection of sites 
spanning Trinidad north to Puerto Rico (Figure 4), dating roughly to the Caribbean's Early Ceramic Age (ca. 400 BC - AD 600).

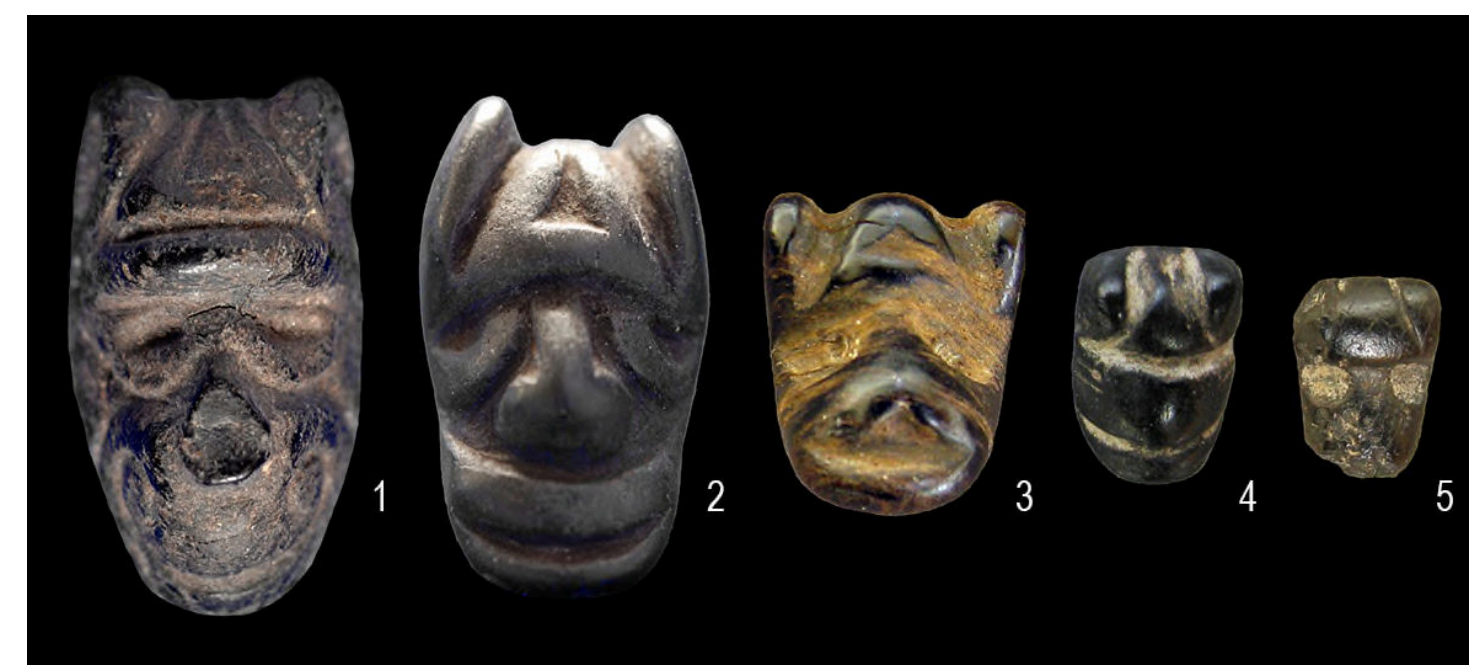

Figure 1: Anthropo-zoomorphic carvings in dark materials, roughly to scale. 1. Carving from Morel, Guadeloupe: H: 27mm; W: 15mm; D: 13mm; courtesy, Museé Edgar Clerc, 94.14.2. 2. L'Allée Dumanoir carving, Guadeloupe: H: 22 mm; W: 12mm; D: 14mm; courtesy, Direction Régional des Affaires Culturells, Guadeloupe, ST3295, 14. 3. Carving from Sorcé, Vieques, Puerto Rico, H: 14mm; W: $11 \mathrm{~mm}$; D: 12mm, S-V, Z-T-B, C-5. 4. Sorcé, Vieques, Puerto Rico amulet, H: 8mm; W: 6mm; D: 8mm, S-V, Z-16. 5. Sorcé, Vieques, Puerto Rico amulet, $\mathrm{H}: 7 \mathrm{~mm}$; W: 5mm; D: $6 \mathrm{~mm}, \mathrm{~S}-\mathrm{V}, \mathrm{Z}-16$. Sorcé carvings courtesy Yvonne Narganes Storde. All photographs: Ostapkowicz. (Figure to be reproduced in colour)

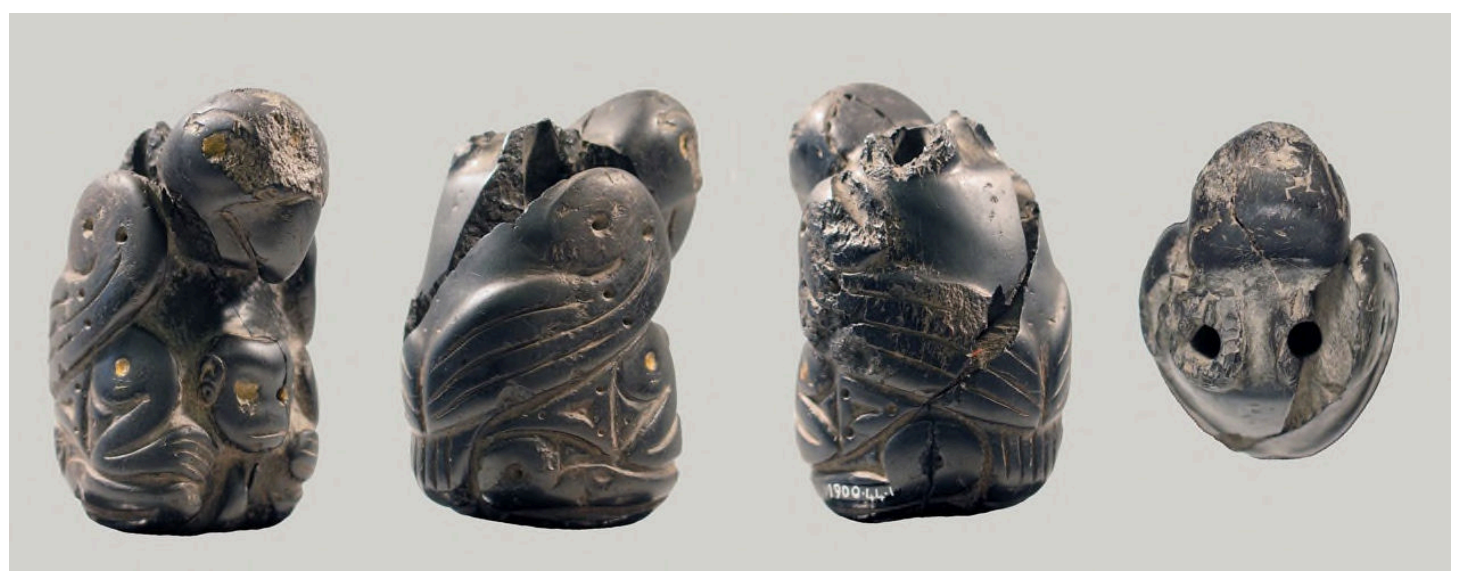


Figure 2. Four views of snuff tube depicting a bird above a monkey, St Vincent, ca. AD 300-800. H: 86mm; W: 53mm; D: ca. 67mm (max). Photograph: Ostapkowicz, courtesy Pitt Rivers Museum, University of Oxford, Acc. No. 1900.44.1. [Figure to be reproduced in colour]
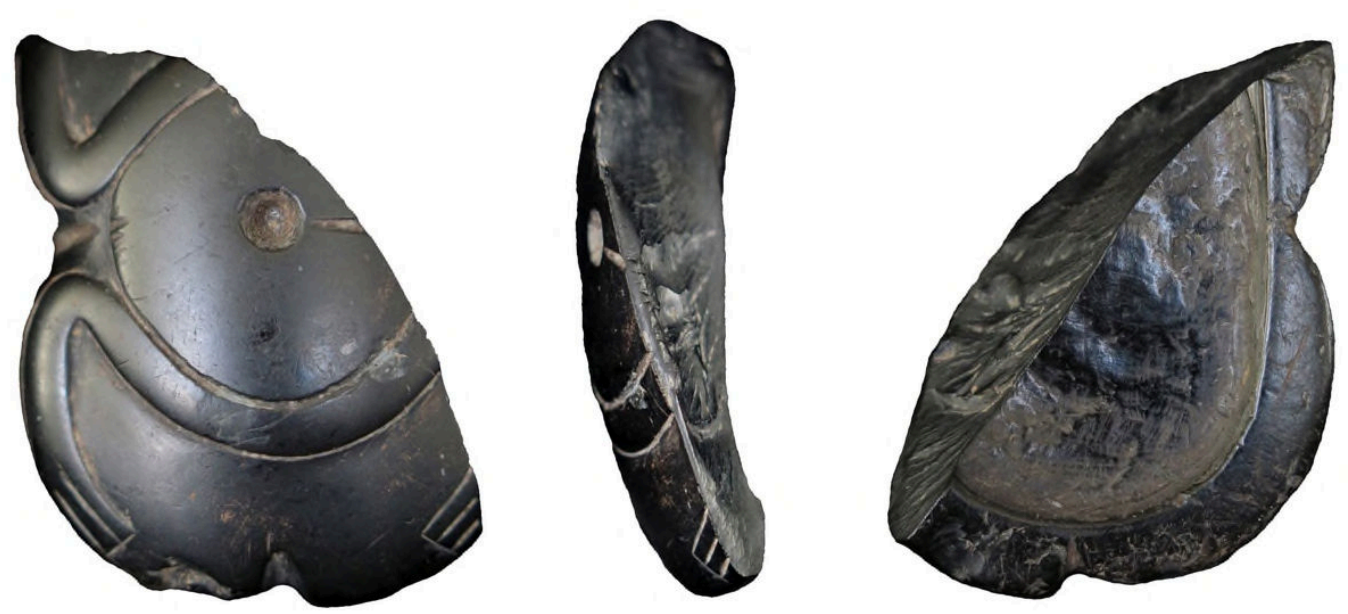

Figure 3. Plano-convex carving featuring a frog design in its ventral surface. L: 49mm; W: 42mm; D: 14mm. Photograph: Ostapkowicz, courtesy and copyright St Vincent and the Grenadines National Trust, 2004.0001.0001.0098. [Figure to be reproduced in colour]

Some of the carvings share almost identical iconography, although they appear at sites hundreds of kilometres apart, such as those found at L'Allée Dumanoir, Guadeloupe (Etrich, 2002; 300 BC - AD 300) and Sorcé, Vieques (Chanlatte Baik and Narganes Storde, 1984: 46-47; 400 BC - AD 600) (Figure 1) or Coto, Puerto Rico (Rainey, 1940: 73-74; ca. AD 900-1200). Their surfaces often have visible structural detail, which have resulted in many being identified as wood (e.g. Petit Roget, 1995). However, lignite may also exhibit visible structure (as noted for carvings by Allason-Jones and Jones, 2001), especially if it contains wood pieces, or merely owing to the tranquil conditions during the accumulation of layer upon layer of organic material. Some jet and 'jet-like' materials may also show structure (e.g. Kool et al., 2009), as may cannel coals which originate as layer by layer accumulations. All of these materials, as well as other dark materials such as asphalt and 
manja(c)k originating in or around Pitch Lake in Trinidad, could possibly have been used to produce carvings

\subsection{The materials}

These dark organic materials are a notable departure from the lustrous exotic minerals such as amethyst, quartz and jadeites that they are sometimes associated with in the Caribbean archaeological record (e.g. Chanlatte Baik and Narganes Storde, 1984: 46-47; Etrich, 2002: 26; 2003: 49$50)$. They therefore raise a number of questions, first and foremost being the identification of the material itself and its potential sources, crucial information that is required before the networks involved in their exchange can be discussed. Further, what does the presence of such similar artefacts (in the case of the anthropo-/zoomorphic pendants) on different islands suggest about the social, cultural and economic links between communities during the Caribbean's Early Ceramic Age? What does the selective use of black materials in the creation of artefacts that specifically functioned within ritual contexts (e.g., drug-related paraphernalia) imply about their significance and symbolic associations?

Small carvings and ornaments in dark materials have also been documented in mainland South America, in particular Venezuela (e.g. Spinden, 1916; Kidder, 1944; Arroyo et al., 1971; Antczak and Antczak, 2006, 2011; Falci et al., 2017). They are sometimes described as jet, 'jet-like' or azabache (the Spanish term for jet) (e.g. Arroyo et al., 1971: 154-155; 233), although one piece previously described as jet (Falci, 2015) was recently stated to be bituminous coal (Falci et al., 2017), with no explanation given for this reclassification.

The identification of archaeological carved black artefacts as jet or 'jetlike' often appears to be based solely on the intense black colouration of the object and its ability to take a high polish, without regard to the actual definition of jet. Jet is generally considered to be formed from compressed, waterlogged drifted wood, which has been secondarily impregnated with bitumen from the surrounding environment (Stach et al., 1982). Only a limited number of deposits are known worldwide, in particular in Europe, including Whitby, United Kingdom (e.g. Muller, 1980; Muller and Muller, 2009), Spain 
(e.g. Suárez-Ruiz and Iglesia, 2007; Gutierrez Blanco et al., 2008) and Utah, USA (where it is described as a 'very peculiar coal' by Traverse and Kolvoord, 1968).

The South American carvings described above may therefore be made of cannel coal, lignite or other hydrocarbon materials, rather than jet. Both cannel coal and lignite are commonly found in Venezuela and Colombia (e.g. Orndorff, 1985).

\subsection{The carvings}

The two artefacts explored in this paper were both 'excavated' from historic museum collections - part of the legacy holdings of the Pitt Rivers Museum, University of Oxford, UK, and the St Vincent National Trust, St Vincent and the Grenadines. The larger of the two carvings (Figure 2) was found on a sugar cane plantation in Charlotte Parish, St Vincent, at some point before ca. 1870, when it was presented by Bishop Michinson, Master of Pembroke College, Oxford, to the Pitt Rivers Museum. It depicts a bird, possibly a parrot or macaw, surmounting a crouched monkey with a long, curled tail. Identified until quite recently as simply a 'figure' (Hicks and Cooper, 2013; 45), it is in fact a central component of a snuff tube used to inhale hallucinogenic snuffs during rituals (Ostapkowicz, in press). It is drilled with two internal tubes which once emerged as raised spouts from the bird's back, now badly broken - these would have been pressed to the nose to deliver the dose, potentially with the aid of short bird bone tubes bringing the narcotic snuff directly into the nostrils. Its style of carving places it within the insular Caribbean's Barrancoid period - roughly AD 300 to AD 600. As such, it is the earliest elaborate snuff tube from the region (for further discussion see Ostapkowicz, in press).

The second carving (Figure 3 ) is held in the collections of the National Trust of St Vincent and the Grenadines. It is a light-weight, black carving identified in museum notes as being made of 'pitch' (asphalt) or 'guttapercha', a tree latex. Its potential provenance is equally varied: if asphalt, it most likely came to St Vincent from Pitch Lake, Trinidad, via prehistoric trade routes. If gutta-percha, it is thought to have been acquired via Barbados (La Verne Phillips, per. com 2015). It is understood to have been part of the 'Old 
Library' collections, curated by Earl Kirby (b. 1921; d. 2005), St Vincent's first qualified veterinarian and, in his spare time, keen amateur archaeologist, who eventually became chairman of the St Vincent Archaeology Society and Director of the National Museum. Unfortunately, the carving had very little associated documentation when it was formally accessioned in 2004, with the hypothetical provenance(s) input at this time.

A stylised frog's body is depicted on the dorsal surface of the broken carving (Figure 3) - its remaining left foreleg, round body and hind legs in the quintessential position of this amphibian depicted in designs common across the span of the Caribbean from the Saladoid period ( ca. 500 BC - AD 500), well into colonial times ( AD 1500) (Waldron, 2016: 187). It is clear from the tool marks on both surfaces that the black material was carved rather than moulded into this shape. The smooth, matte finish of the dorsal surface must have been achieved by fine-grained sanding and polishing. The ventral surface appears to be shallowly excavated with a thick rim ridge; together with its small size and smoothly rounded dorsal surface - which perfectly fits the palm of the hand - these elements potentially suggesting a personal snufftray for small doses of a potent narcotic substance.

\subsection{Geological materials}

Identification of the materials from which these black Caribbean carvings are made may help identify their geological origin, and hence improve understanding of trade and exchange routes in the pre-Columbian circum-Caribbean. Carvings made of cannel coal, for example, are most likely to have originated in South America, where it is common (in particular in Venezuela and Colombia), as deposits are not known to be present in the Caribbean (Sealey, 1986). The identification of the material as either lignite or lignitic (i.e. highly mineral-containing) would be less informative, as these materials occur in both South America (e.g. Orndorff, 1985) and the Caribbean, where they are found in Trinidad (Orndorff, 1985; Babalool et al., 2016) and throughout the Greater Antilles, eastwards from Cuba, across parts of Jamaica, Haiti, the Dominican Republic, and Puerto Rico (e.g. Orndorff, 1985; Iturralde-Vinent and Hartstein, 1998; Iturralde-Vinent, 2001; Sealey, 1986; Graham, 1996) (Figure 4). Most of these lignite and lignitic deposits are 
not extensive enough (or are found at depth, and hence likely unavailable to pre-Columbian artisans), or the material is not sufficiently consolidated, to be suitable for carving (Alan Graham, pers com. 2018). However, it is not inconceivable that some small, high quality exposed deposits do exist, which might have been of particular interest to a carver skilled in working other materials.

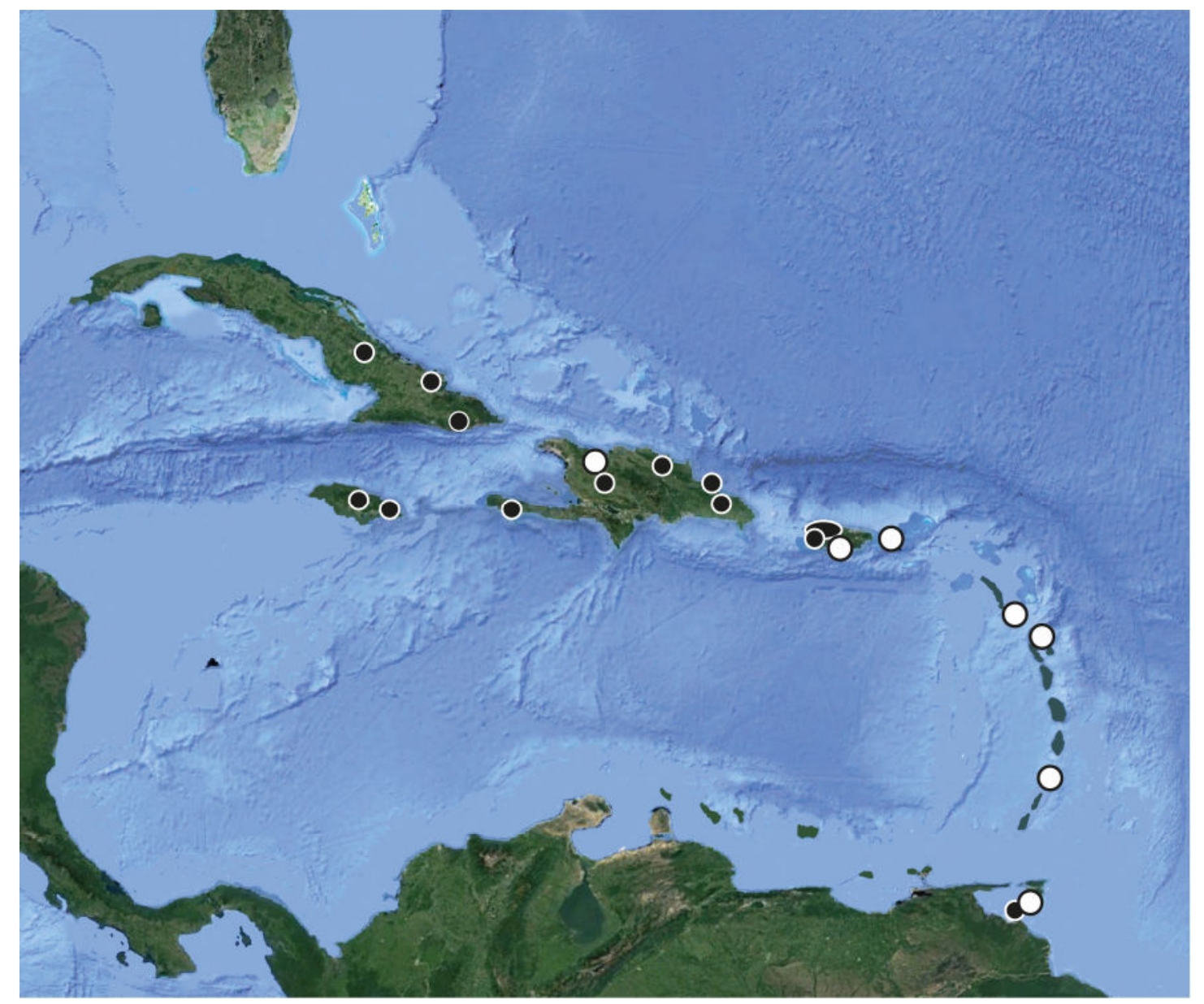

Figure 4: Map of the Caribbean, indicating locations of finds of black PreColumbian carvings (white circles) and known locations of lignite (black markers) (e.g. Orndorff, 1985; Babalool et al., 2016; Iturralde-Vinent and Hartstein, 1998; Iturralde-Vinent, 2001; Sealey, 1986; Graham, 1996).

It is also possible that hydrocarbon materials such as asphalt, bitumen, and manja(c)k associated with Pitch Lake (Trinidad) and the Scotland District 
(St Andrew's parish) of Barbados (e.g. Sealey, 1986) were carved, as similar solid hydrocarbons such as albertite are known to have been carved elsewhere, including Scotland, UK (e.g. Sheridan, 2015). While some of these materials may not have been suitable for carving once exposed and solidified, they may have been softer and workable prior to exposure to air, in a similar manner to that of Turkish black amber or Oltu stone (e.g. Kalkan et al., 2012). However, Boomert (2016: 40) considered the black carvings found in Trinidad likely imports from the Lower Orinoco Valley in Venezuela, despite the local availability of lignite and materials associated with Pitch Lake. Waldron (2016: 37) also describes one black anthropomorphic carving from Montserrat as 'probably hardened asphalt or pyroclastic materials' although the basis for this identification is unclear, and the original museum accession card records the piece as 'cannel coal'.

The suggestion in the records of the St Vincent National Trust that the frog carving may be made from 'gutta percha' is intriguing, though likely a result of historic misattribution. Historically carved for jewels and ornaments (Prakesh et al., 2005), gutta percha is a tree latex produced by native Indonesian woods of the Sapotaceae family (Clouth, 1903), and hence unlikely to be the origin of the Caribbean material. A similar substance, balata (originally described as 'Surinam gutta-percha') is produced by trees from the same family found in the Caribbean and South America (Clouth, 1903). However, historical balata carvings appear dull brown in colour and are visually very distinct from the black Caribbean carvings of this study (e.g. Albuquerque, 2018).

\subsection{Material identification}

The materials that were likely used for both of the St Vincent carvings (Figures 2 and 3), as well as others found in both the Caribbean and South America, are all composed of plant material that has been degraded, compacted, and sometimes heated or impregnated, to varying extents over many millennia, and with differing degrees of mineral impurities. These variations in composition result in different properties in terms of carving ability, resilience and lustre (Teichmüller, 1992). However, the individual materials cannot be identified by eye, which can be challenging for 
archaeologists, especially those studying large assemblages of artefacts carved in a range of materials (e.g. Sheridan, 2017; Woodward and Hunter, 2015).

Identification of the carving material can be further complicated because of variations in the definitions of each of the hydrocarbon materials, with a lack of clearly defined physical and/or chemical characteristics for each one. Several studies have used traditional organic petrology techniques (such as reflected light microscopy and vitrinite reflectance) and/or palynology to identify archaeological coal artefacts (see Suárez-Ruiz et al., 2012, for a more detailed review). However, these techniques are often not suitable for individual archaeological carvings, requiring destructive sampling to allow for preparation of thin sections, palynology slides or mounting in resin blocks to be polished. These techniques also require a detailed understanding of petrographic techniques and comparative local geological samples (e.g. Kalkreuth and Sutherland, 1998; Kalkreuth et al., 2012), which is often available for European samples, but not currently for those from the Caribbean or South America.

Current approaches to the identification of materials found in European black lithic assemblages include consideration of colour and texture, and degradation, surface polish and fracture characteristics (e.g. Sheridan, 2017; Woodward and Hunter, 2015), supported where possible by analytical techniques including $\mathrm{x}$-radiography (e.g. Sheridan et al., 2002) reflected light and reflectance microscopy (e.g. Allason-Jones and Jones, 2001) and x-ray fluorescence spectrometry (e.g. Woodward and Hunter, 2015; Gormley, 2017). Various studies have applied a further range of analytical techniques to European assemblages in efforts to distinguish between different carving materials (usually including jet, lignite, oil shales, and/or cannel coal) and to potentially identify source materials, whilst minimising (or removing entirely) the need for destructive analysis, with varying degrees of success. These techniques include ESR (Sales et al., 1987; Hunter et al., 1993), ${ }^{13} \mathrm{C}$ NMR (Lambert et al., 1992), FTIR (Hunter et al., 1993; Watts and Pollard, 1998), py-GC/MS (Watts et al., 1999) and LA-ICP-MS (Baron and Gratuze, 2016).

This study applies four complimentary techniques (XRF, FTIR, reflectance microscopy, py-GC/MS) to the two St Vincent carvings, to 
determine the most suitable techniques to identify the material type with minimal requirement for destructive sampling ${ }^{1}$. The techniques were applied to analyse a range of characteristics (trace element and organic composition, physical structure and biological constituents), to determine what they are made of, and hence where they might have originated.

\section{Materials \& Methods}

\subsection{Samples}

The two carvings (Figures 2 and 3 ) were each sampled carefully with a clean scalpel blade, ensuring the minimum amount of material was taken as discretely as possible. Small scrapings of the carving were removed from the margins of an internal crack near the base of the bird/monkey snuff tube (Pitt Rivers Museum, University of Oxford, UK). The largest piece measured $5 \mathrm{~mm}$ at its widest point and was ca. $2 \mathrm{~mm}$ thick.

The frog carving (St Vincent and the Grenadines National Trust) was sampled on the broken surface to ensure a discrete sampling that in no way affected the carved ventral or dorsal surface (Figure 5). A natural semicircular crevice within the break provided good leverage for the scalpel to extract $12.2 \mathrm{mg}$ of thin, sliver-like fragments. The material was soft and easy to sample, but also fragmented easily in storage after sampling.

\footnotetext{
${ }^{1}$ Several samples from this study are additionally undergoing PIXE-PIGE analysis at the Louvre Laboratory as part of wider study of jet and similar materials under the direction of Dr Lore Troalen, National Museum of Scotland.
} 


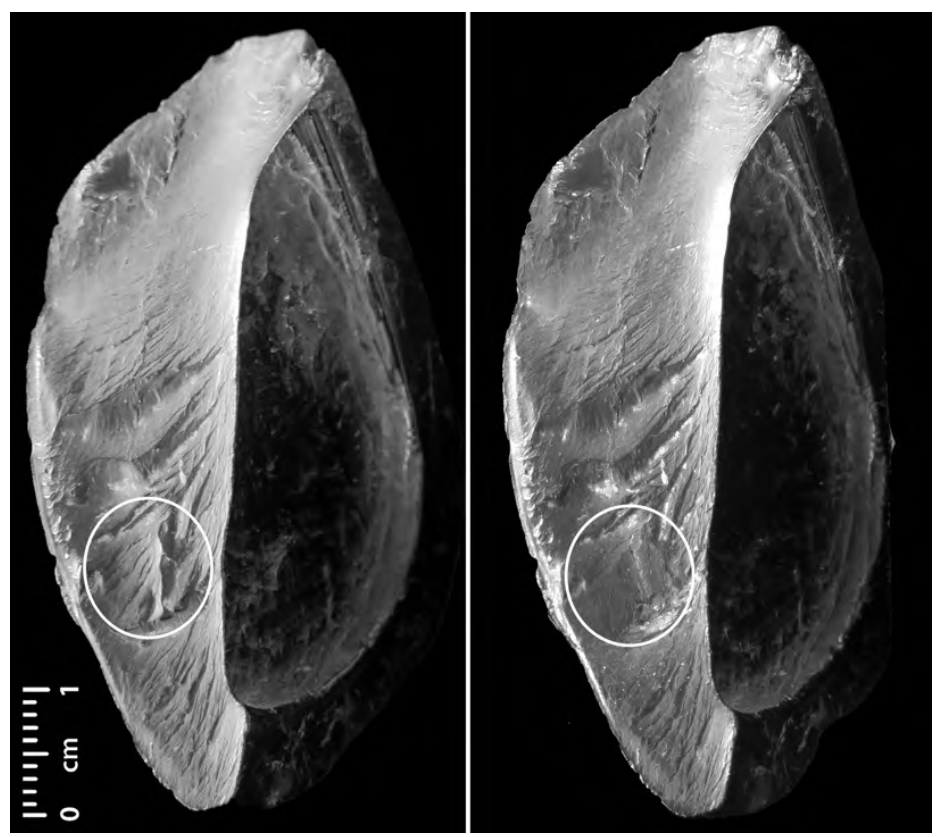

Figure 5: The broken surface of the frog carving (tilted slightly to the left when compared to the central image in Figure 3), showing the sampling target area (circled) before (left) and after (right) sampling. Photos: Ostapkowicz, courtesy St Vincent and the Grenadines National Trust, 2004.0001.0001.0098.

Five comparative source materials were chosen for analysis in this study, as follows:

- Jet from Whitby, Yorkshire, UK (obtained from Yorkshire Coast Fossils, UK).

- Lignite, origin unknown, supplied as part of a reference hydrocarbon specimen set (obtained from UKGE Ltd., UK.)

- Cannel coal from La Pajarita in the state of Táchira, western Venezuela (sample M13-LP; Hackley et al., 2005).

- Solidified surface crust material collected from Pitch Lake, Trinidad. This material is dull, matt, dark grey/black in colour, with a heterogeneous appearance, and includes small amounts of fresh plant material. 
- A sample of black, glassy, solidified, weathered pitch-like material (possibly manjak) collected from a beach along the coast from Pitch Lake, Trinidad.

The two samples from Pitch Lake, Trinidad (henceforth 'crust' and 'beach') were not subjected to all analyses as their visual appearance was too distinct from that of the carving material: the crust material was too dull and matt, and the beach sample was too glassy. Neither material appeared suitable for carving, although they may have been chemically representative of material that might have been softer prior to hardening on exposure to air.

\subsection{Reflectance microscopy}

Samples were embedded in resin (EpoFix epoxy supplied by Struers) and polished (using 60-, 240-, 400-, and 600- grit SiC papers followed by 0.3 micron alumina on Buehler Texmet paper and 0.05 micron alumina on silk) to provide a surface for study. The blocks were made perpendicular to any lineation where it was visible within the sample. Polished blocks were viewed in reflected light under immersion oil (Cargille type $A$, density $0.923 \mathrm{~g} / \mathrm{cc}$ at $23^{\circ} \mathrm{C}$, RI of 1.514 ) using a Leica reflected light microscope and either $\times 20$ or $\times 50$ oil immersion objectives.

All specimens were examined from side to side and top to bottom (one transect each) to check for uniformity or variability. Areas with scratches on the blocks were avoided for photography where possible. All images are representative of the samples and all were taken under the same lighting conditions, with the same brightness and contrast settings. Focussing was difficult, especially in the jet sample, which by its nature is a very low reflectance material such that edges of features on which to focus are scarcely visible. Some images (Figure 6) had to be adjusted to make the features visible in the figure and so not all images are directly comparable with one another in terms of brightness and contrast as it is seen under the microscope. 


\subsection{FTIR}

The samples were analysed by Fourier Transform Infrared (FTIR) spectroscopy using a Bruker Alpha mid-IR optical benchtop FTIR equipped with a standard in-compartment horizontal attenuated total reflectance (ATR) accessory fitted with a diamond crystal (Platinum ATR).

Due to the limited amount of material available for each sample, and variations in ease with which the material could be roughly crushed, the samples varied in size from less than a millimetre in largest dimension to well over five millimetres. A small portion of each sample - sufficient to substantially cover the surface of the diamond sensor element - was pressed into intimate contact with the crystal, using the built-in compression anvil, as is usual. Good contact was judged from the quality of spectral response observed, using strength of absorbance as the key metric.

The mid-infrared response of each sample was recorded between 4000 and $400 \mathrm{~cm}^{-1}$ wavenumbers, at $4 \mathrm{~cm}^{-1}$ spectral resolution. 256 scans were collected for each sample to achieve high-quality data. Bruker Opus MENTOR software was used to control the system and to manipulate the data; this included automatically ratio-ing the sample's spectrum against a reference spectrum, as is usual practice.

Prior to analysis, the background reference spectrum was acquired with no sample loaded onto the sensor crystal. Both the sensing region and the tip of the anvil were cleaned with isopropanol before each background, and before loading each new sample; mechanical abrasion was also used if residual material from the previous analysis was tenacious. In addition, the background was re-acquired periodically, to mitigate the impact of any residual material on subsequent analyses.

The data have not been modified, post-collection: no data treatments have been applied. As a result, care must be taken when comparing the data to reference spectra collecting using other techniques (such as transmission through pressed pellets, by external diffuse or specular reflection, or by photoacoustic means; see Monnier (2018) for further discussion. There are well-known optical effects to consider when using the internal reflection (ATR) geometry. We simply note here that in order to compare accurately ATR data with transmission data, one should correct for the impact of variable 
penetration depth on relative signal intensity, as a function of wavenumber; and also correct for asymmetric band shape and apparent shift in band position, due to the effects of anomalous dispersion in regions of strong absorption.

\subsection{Pyrolysis-GC/MS}

Sample material from both carvings and the cannel coal comparative sample were analysed by py-GC/MS using a Chemical Data Systems (CDS) 5150 pyroprobe pyrolysis unit attached to an Agilent 6890A gas chromatograph (GC) fitted with a CPSil-5CB fused column (Varian 100\% dimethylpolysiloxane; $50 \mathrm{~m}, 0.32 \mathrm{mmi} . \mathrm{d}$.; $0.45 \mu \mathrm{m}$ film thickness) and a ThermoElectron MAT95 double focussing mass spectrometer (ThermoElectron, Bremen) operated in electron ionization (EI) mode (EI source temperature $200^{\circ} \mathrm{C}$, interface $310^{\circ} \mathrm{C}$ ) with helium as a carrier gas $(2$ $\mathrm{mL} \mathrm{min}^{-1}$ ). Samples were pyrolysed in a quartz tube at $610^{\circ} \mathrm{C}$ for $20 \mathrm{~s}$, transferred to the $\mathrm{GC}$ using a pyrolysis transfer line $\left(310^{\circ} \mathrm{C}\right)$ and injected onto the GC using a split ratio of 10:1; the injector port temperature was maintained at $310^{\circ} \mathrm{C}$. The oven was programmed to heat at $4^{\circ} \mathrm{C}^{-1} \mathrm{~min}$ from $50^{\circ} \mathrm{C}$ (held for $4 \mathrm{~min}$ ) to $300^{\circ} \mathrm{C}$ (held for $15 \mathrm{~min}$ ). The MS scanned the range $\mathrm{m} / \mathrm{z} 50-650$ at a rate of one scan per second and there was a filament delay of 7 min. Data were collected using MAT95InstCtrl v1.3.2 and viewed using QualBrowser v1.3 (ThermoFinnigan, Bremen). Compounds were identified using the National Institute of Standards and Technology (NIST08) database and by comparison with spectra from the literature (including Watts et al., 1999) and an in-house library. A sub-sample of Pitch Lake crust material was previously analysed by Brock et al. (2017).

\subsection{X-ray fluorescence (XRF) spectrometry}

Aliquots of all five geological specimens and both carvings were analysed as powders using benchtop XRF. The benchtop XRF is more sensitive, but hand-held $(\mathrm{HH})-\mathrm{XRF}$ was also used for the bird/monkey artefact, to investigate its potential for future analysis of similar objects on-site in collections/museums. 


\subsubsection{XRF (benchtop)}

The elemental compositions of all seven samples were assessed by using a SciMed SEA6000VX X-ray fluorescence spectrometer. Measurements were taken over a $0.5 \times 0.5 \mathrm{~mm}$ area in air at the instrument's normal focusing distance, with its X-ray tube operating at $50 \mathrm{kV}, 1000 \mu \mathrm{A}$ without any filtration. Each spectrum was collected for $1200 \mathrm{~s}$ and a semi-quantitative calculation of concentrations of the metallic components of the samples was obtained by using the instrument's standard fundamental parameters program with the balance of the sample assumed to be carbon.

\subsubsection{Hand-held XRF}

Analysis of the surface of the bird/money carving was undertaken on-site in the Conservation Department at the Pitt Rivers Museum using an Oxford Instruments XMET 8000 light element handheld XRF. The instrument has a $5 \mathrm{~mm}$ diameter spot size and analysis areas were selected using a cross-hair on an in-built positioning camera. Measurements were taken using the AlloyLE (light elements) fundamental parameters dual condition set which alternates between $8 \mathrm{kV}, 40 \mu \mathrm{A}$ with a $500 \mu \mathrm{m} \mathrm{Al}$ filter and $40 \mathrm{kV}, 8 \mu \mathrm{A}$ with a $25 \mu \mathrm{m}$ Fe filter. The program produces a spectrum for each condition set which meant that elements ranging from magnesium to uranium could potentially be identified. 60 second acquisition times were used for all measurements.

A small area (approx. 10mm diameter) of thin wax coating (presumed to be a historical conservation treatment) was removed from the surface of the object by swabbing with a mixture of IMS (industrial methylated spirit) and white spirit to allow analysis of the underlying material. Three measurements were taken on both the surface coating and the cleaned area so that elements derived from the coating could be distinguished.

Bruker Artax software was used to identify elemental peaks and to calculate the number of counts that contributed to each peak ('peak area analysis'). Full quantification of the data was not possible due to the lack of suitable reference material of the same matrix as the sample. 


\section{Results and discussion}

\subsection{Reflectance}

Reflectance microscopy of polished blocks under oil is widely used in the study of coals, lignites and charcoal, and it enables recognition of structure, tissues and cells in otherwise dark materials (e.g. Allason-Jones and Jones, 2001). Interpretations here are based on prior experience of one of the authors (MEC) where the following are examples (Collinson et al., 2007; Steart et al., 2007; Hudspith et al., 2012; Robson et al., 2015; Noorbergen et al., 2018 supplementary material).

The cannel coal sample (M13-LP) is approximately parallel laminated at a very fine scale and contains a wide variety of components (Figures 6a,b). The regions in various dark shades of grey contain various-sized clumps or layers of material within a darker, almost black, background matrix lacking obvious plant tissue cell structure. Whilst some of the paler grey regions are almost structureless, others have well-defined morphology. The single isolated rings may be derived from plant or fungal material such as isolated lignified walls of wood cells (separated after decomposition), fungal spores, pollen, or a mixture of all three. Multicellular fungal sclerotia are also present. There is no obvious multicellular plant tissue. 

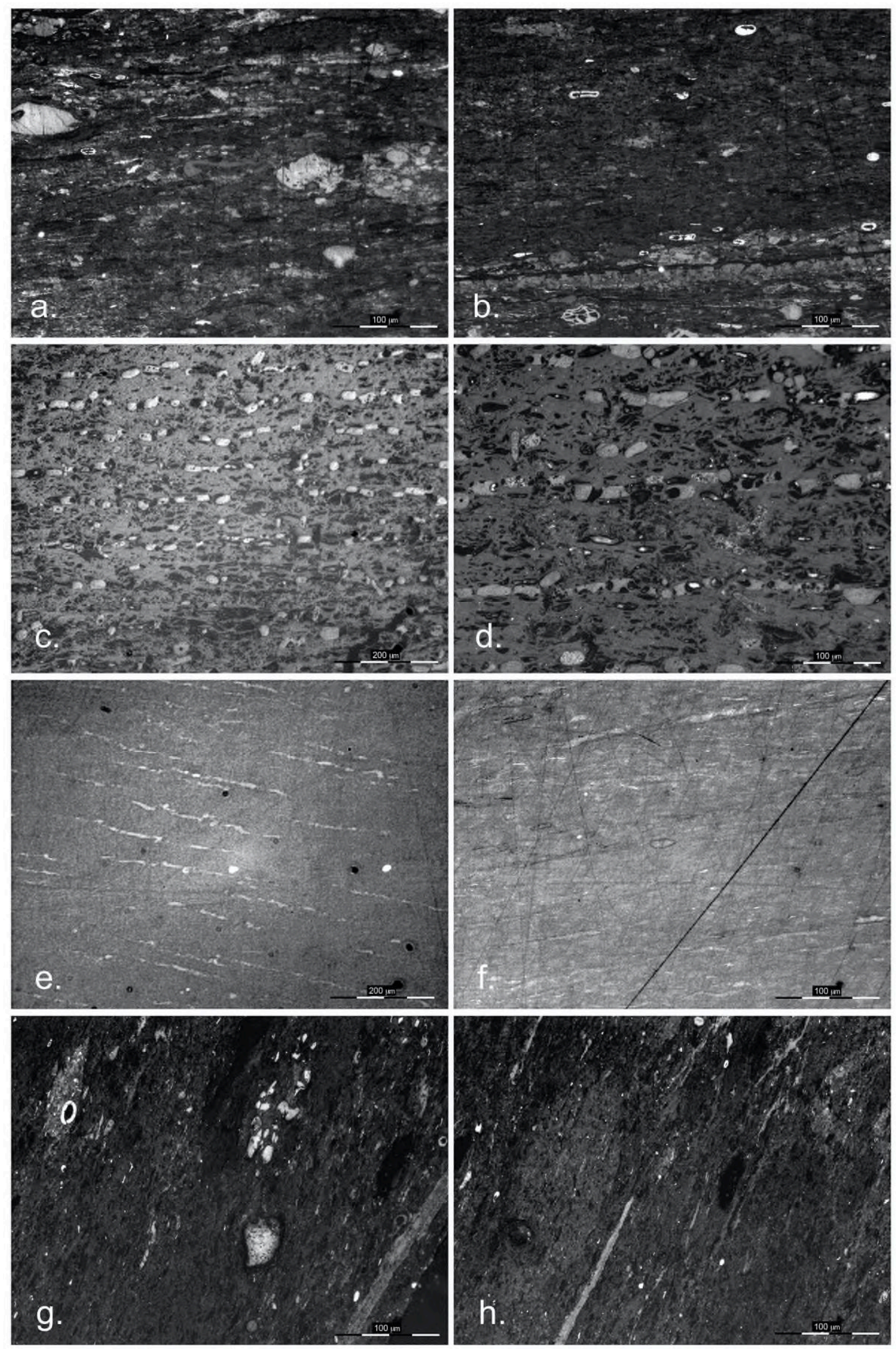

Figure 6: Reflectance microscopy images from polished blocks under oil: a, b: cannel coal; c, d: lignite; e, f: Whitby jet; g, h: bird/monkey carving. 
The lignite sample (Figure 6c, d) appears to consist of a single piece (or organ) of only one type of multicellular plant tissue. This therefore differs from other lignites which can be formed from multiple types of multicellular plant tissues. The specimen is uniform throughout showing a repeated pattern of (i) discontinuous layers (left to right in image), a single cell thick, where cells have infills (very light grey) and (ii) multiple layers (darker grey) of varied cell sizes often without infills (black spaces). This is consistent with considerably decayed wood if the obvious layers with pale infill represent the parenchymatous rays and the woody xylem cells between have been both degraded and distorted due to compression with some still having open cell lumina.

Two fragments of Whitby jet were examined and both were extremely difficult to image or interpret owing to the minimal reflectance observed, which is typically characteristic of jet (Stach et al., 1982), combined with residual scratches from the polishing. Unlike the cannel coal sample, the jet specimens lack multiple distinctive components (such as spores or fungal sclerotia). The jet samples also do not show the very fine parallel laminations characteristic of the cannel coal sample.

Layering is clearly visible across parts of both jet specimens (Figure $6 e, f)$ - where one type of layer is visible as very pale discontinuous bands (oblique to the horizontal in the images). The very pale discontinuous bands (most obvious in Figure 6e) are consistent with strongly compressed former parenchymatous rays in wood (comparable to the interpretation of the lignite sample above (Figure $6 \mathrm{c}, \mathrm{d}$ ) as a single piece of wood). In the slightly darker grey bands, a few elongate oval spaces (interpreted as original cells) are visible at the microscope, some with infills. Most of the sample is compacted and appears structureless, i.e. any original cell lumina have been occluded completely.

The Pitch Lake solidified surface crust showed only uniform very dark material closely resembling its visual appearance in hand specimen. No physical features could be distinguished. This is completely different from the lignite, jet and cannel coal comparative samples. 
Owing to the very small and thin sample (ca. $1 \mathrm{~mm}$ ) that was available for the frog carving it was decided not to attempt embedding and polishing for reflectance microscopy.

The largest fragment of material collected from the bird/monkey carving measured a maximum of $4 \mathrm{~mm}$ by $3 \mathrm{~mm}$, and was less than $2 \mathrm{~mm}$ thick. Despite the limited amount of material, a lot of detailed structure is visible showing multiple components in a very finely laminated sample (laminations slightly oblique to the vertical in the images; Figures $6 g, h$ ). Of the four comparative dark materials studied (cannel coal, lignite, Whitby jet and Pitch Lake crust), the bird/monkey sample most closely resembles the cannel coal, and is clearly not jet or Pitch Lake solidified surface crust.

\section{$3.2 \mathrm{FTIR}$}

FTIR has the potential to distinguish between different geological source materials as the spectra reflect both the original plant material and any additional mineral phases present (Watts and Pollard, 1998). As each sample is comprised of a mixture of a wide range of organic compounds, individual peaks cannot be assigned to specific molecules or constituents, but the spectra can be used to distinguish between material types and to corroborate other techniques. This approach considers each recorded spectrum to be the signature of a given sample; generated by the superposition of the unique spectral contributions from each constituent.

The samples of Whitby jet, lignite and cannel coal were analysed both for comparison with previously published spectra (e.g. Hunter et al., 1993; Watts et al., 1997; Watts and Pollard, 1998), as well as the spectra of the two carvings, and the Pitch Lake crust and beach samples. However, natural variations between specimens of the same type are to be expected due to the heterogeneous nature of the materials and natural variations between (and within) deposits. As the lignite specimen appears to be formed from a single plant tissue (as observed by reflectance microscopy), the sample may be less heterogeneous than most other lignite specimens.

It should also be noted that the spectra presented in Fig 7a, while very similar to those of Watts and Pollard (1998) cannot be compared directly due to differences in the techniques used. Watts and Pollard (1998) analysed 
powdered samples pressed into $\mathrm{KBr}$ pellets and measured in transmission mode, while this study directly analysed small fragments or rough powders by ATR in absorbance mode.

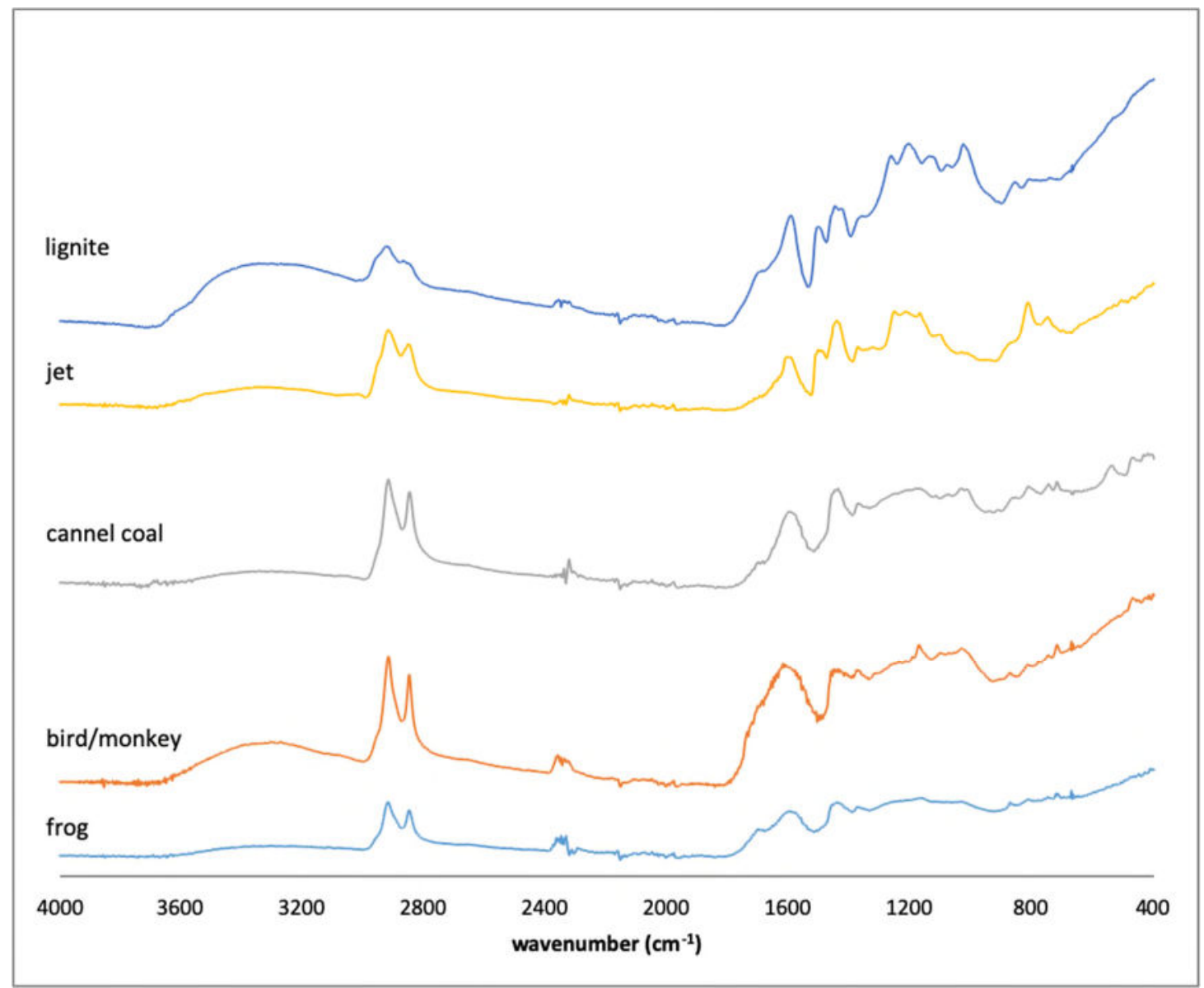

Figure 7a. FTIR spectra of lignite, Whitby jet, cannel coal, the bird/monkey carving and the frog carving.

The spectra for Whitby jet, lignite and cannel coal (Fig 7a) are consistent with those published by Hunter et al. (1993) and Watts and Pollard (1998). The lignite and jet spectra both have a distinct aromatic $\mathrm{C}=\mathrm{C}$ stretch at ca. $1500 \mathrm{~cm}^{-1}$, which has previously been recorded in the spectra of jets from Spain, the UK and USA, as well as 'unusual' coals (Iglesias et al., 1995; 
Watts et al., 1997; Traverse and Kolvoord, 1968). This peak is not observed in most coal samples (Watts et al., 1997; Watts and Pollard, 1998) and is absent in the cannel coal sample in this study as well as both the bird/monkey and the frog carvings. There is great variation in the region of $\mathrm{C}-\mathrm{H}$ deformation between 900-700 $\mathrm{cm}^{-1}$ (Watts and Pollard, 1998); both the jet and lignite spectra are more distinctive in this region than the other geological materials, with jet having a sharp peak at ca. $850 \mathrm{~cm}^{-1}$ absent in all other spectra.

In general, the spectra for both the bird/monkey and frog carvings can be considered to most closely resemble those of the cannel coal, although all 3 of these spectra have small, but distinct, differences. The absorption for the frog sample is poor compared to the other samples, which may reflect poor sample contact during analysis. Poor contact between sample and sensor element is well-known to yield poor spectral response in ATR spectroscopy - it can be especially troublesome where the material is mechanically hard, because it is difficult to achieve good contact over a sufficiently large area. Whilst this can be mitigated by preparation of a fine dispersion by grinding or milling, care must be taken to avoid processing the material in ways that lead to structural or compositional changes that would intrinsically alter the spectral response. It is also vital that there is sufficient material present to ensure good contact. Analogous concerns apply over preparation of samples for transmission spectroscopy; any method that requires sample preparation and/or intimate contact should be used circumspectly.

The peak at ca. $1020 \mathrm{~cm}^{-1}$ is most likely indicative of alumino-silicates (Watts and Pollard, 1998). This is seen to varying extents in all samples except the Whitby jet sample, but is most distinct in the Pitch Lake crust and lignite samples. Its presence in the cannel coal spectra is supported by the presence of high concentrations of kaolinite (hydrated aluminium silicate) measured in the same specimen by Hackley et al. (2005). 


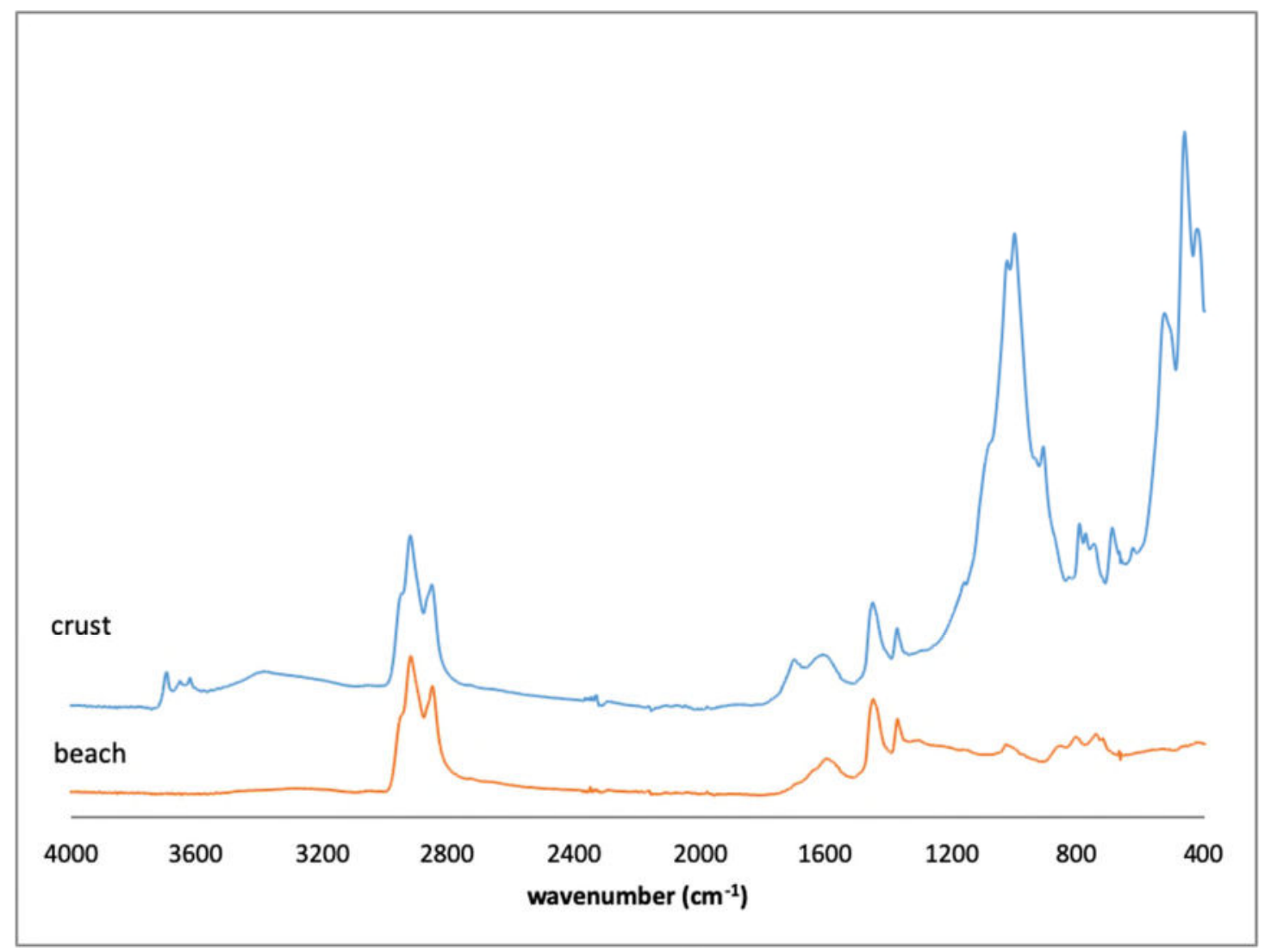

Figure 7b. FTIR spectra of Pitch Lake crust material and Trinidad beach specimen.

The Pitch Lake materials (Fig $7 b$ ) are considered separately from the other samples, as they are visually very distinct from the carvings and are thus unlikely to be from the same source. The spectra for the crust material demonstrate a very different mix of constituents from those of all other samples and the carvings, especially in the 1200 to $400 \mathrm{~cm}^{-1}$ range, most likely due to higher mineral input, as well as fresh plant material. The spectrum of the beach specimen is similar to that of the crust in the 3000 to $1300 \mathrm{~cm}^{-1}$ range, but is otherwise distinctive.

\subsection{Pyrolysis-GC/MS}

Figure 8 depicts partial chromatograms for material taken from: (a) the $\mathrm{bird} /$ monkey carving, (b) the frog carving, and (c) cannel coal. All three chromatograms are dominated by a homologous series of $n$-alkene/ $n$-alkane doublets, ranging in carbon chain-length from $\mathrm{C}_{9}$ to $\mathrm{C}_{33}$, indicative of the 
highly aliphatic nature of the materials analysed with little contribution from aromatic compounds, although low amounts of phenol, 2-methylphenol, 3methylphenol, dimethylphenol and methyl naphthalene are present in each (as identified by comparison with Larter, 1984). The bird/monkey carving also exhibits a dominant peak which was identified as naphthalene. 


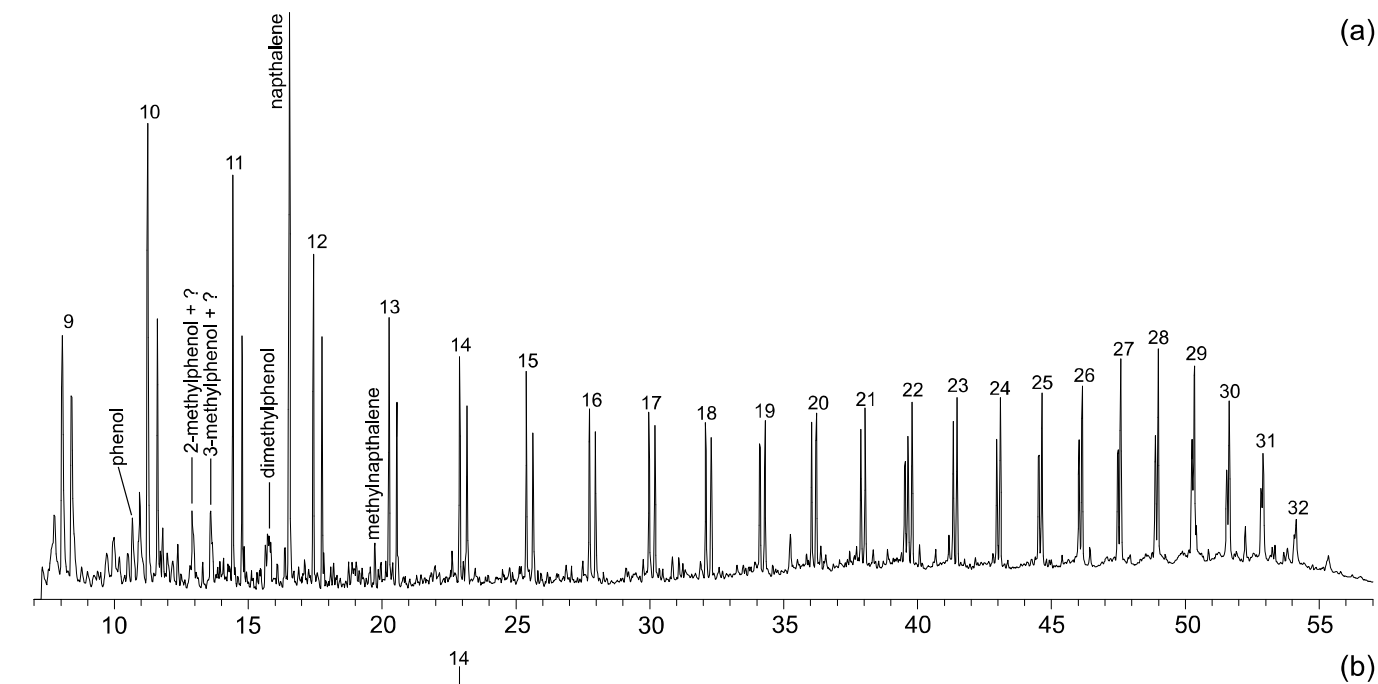

(a)
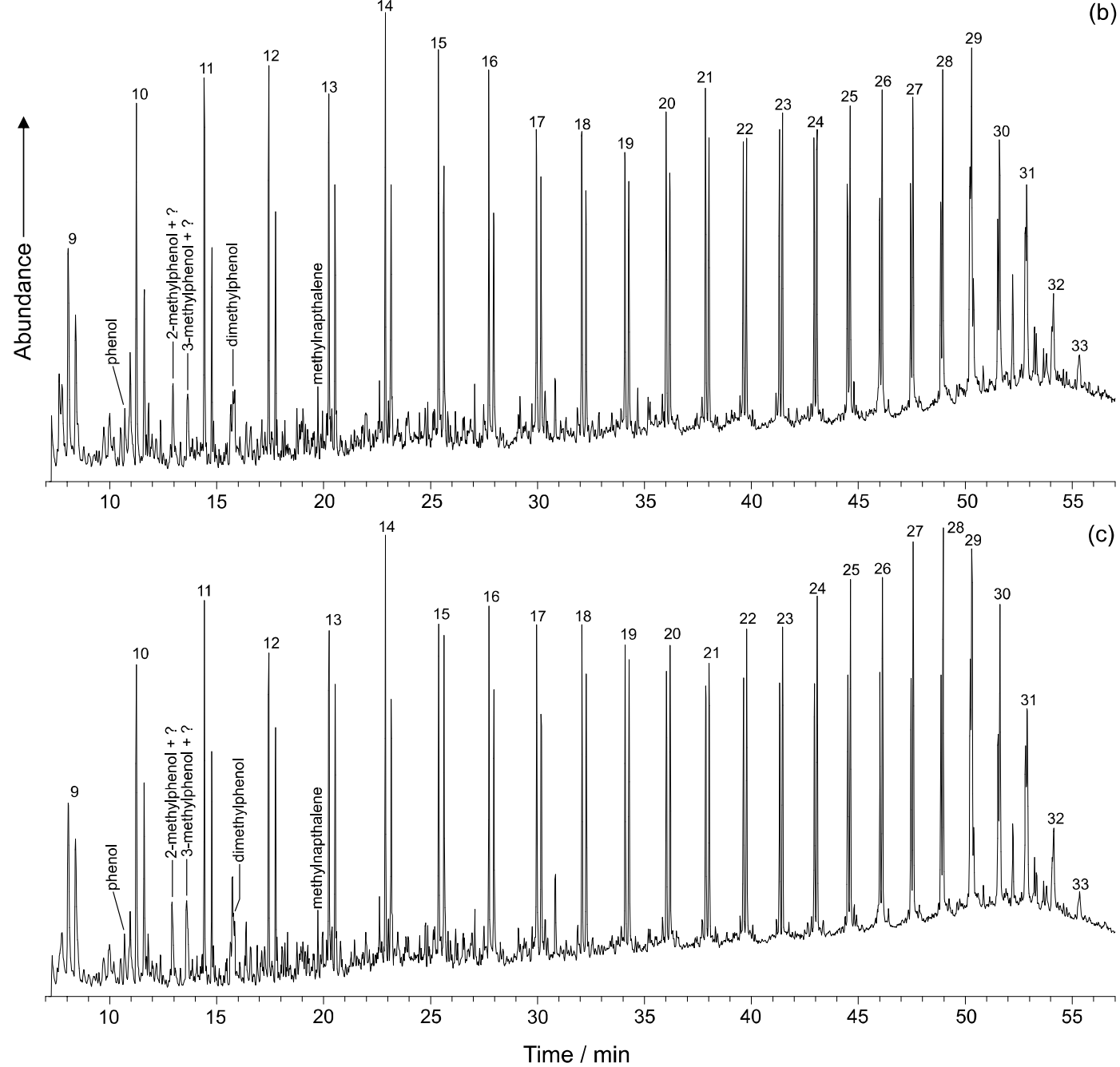

Figure 8: Partial chromatograms obtained by py-GC/MS analysis of: (a) $\mathrm{bird} /$ monkey carving, (b) frog carving, and (c) cannel coal. Integers indicate the carbon numbers of $n$-alkene/ $n$-alkane doublets. 
None of the distributions shows an odd-over-even predominance for the $n$-alkanes. The relative distributions of the $n$-alkene/ $n$-alkane doublets for the frog carving and cannel coal are almost identical with roughly similar relative amounts of each homologue, barring the peripheral homologues $\left(\mathrm{C}_{9}\right.$, $\left.\mathrm{C}_{30}-\mathrm{C}_{31}\right)$. In comparison, the low molecular weight homologues $\left(\mathrm{C}_{10}-\mathrm{C}_{13}\right)$ observed for the bird/monkey carving dominated over the rest of the distribution. Previous work by Brock et al. (2017) reported distributions of $n$ alkene/ $n$-alkane doublets observed in partial py-GC/MS chromatograms obtained for the solidified surface crust material collected from Pitch Lake, Trinidad. Whilst the homologous series described the same range ( $\mathrm{C}_{9}$ to $\mathrm{C}_{33}$ ), the distributions determined for the artefacts and cannel coal characterised in this study exhibit a far more uniform distribution across the range, indicative of a more terrigenous source of organic matter (Peters et al., 2005).

The py-GC/MS results obtained for the cannel coal are consistent with those obtained in previous work concerned with the provenance of archaeological artefacts made from various black lithic materials (Watts et al., 1999). However, the frog carving does not yield results that are consistent with those observed previously for samples of Whitby and Kimmeridge jet, lacking the predominance of phenolic over aliphatic moieties materials which characterises such materials (Watts et al., 1999). Moreover, the close match between the frog carving and the cannel coal py-GC/MS results strongly suggests that the carving is made from cannel coal (or some closely related material) rather than jet or lignite.

Whilst the elevated (relative to the whole distribution) low molecular weight $n$-alkanes $\left(\mathrm{C}_{10}-\mathrm{C}_{13}\right)$ observable for the bird/monkey carving may indicate a different source material from that used for the frog carving, it is also possible that these homologues constitute the additional contamination associated with conservation treatments previously mentioned. Removal of them would result in a chromatogram more closely matching those of the frog carving and cannel coal indicating a similar origin. Similar to the frog carving, the bird/monkey carving was not manufactured from jet as the chromatogram does not show the predominance of phenolic over aliphatic moieties so characteristic of this material (Watts et al., 1999). The occurrence of naphthalene in the bird/monkey carving is not unsurprising as it is naturally 
present in some coals, but concentrations may be artificially high due to the presence of pesticide residues remaining from historic treatments applied to the Pitt Rivers collection (Charlton et al., 2014).

\section{$\underline{3.4} \underline{\mathrm{X} \text {-ray fluorescence }(\mathrm{XRF}) \text { spectrometry }}$}

\subsubsection{Benchtop XRF}

Previous studies of European jet and similar materials suggested that XRF was capable of distinguishing between archaeological artefacts of jet, non-jet, and shale (Pollard et al., 1981; Hunter et al., 1993). These studies suggested that iron was the most discriminatory element, with very low levels associated with jet, and higher (but varying) levels in non-jets such as cannel coal and oil shale. However, more recently Sheridan (2015) reported higher iron levels in some jet relating to, for example, pyrite inclusions. Most shales also exhibit high levels of aluminium and silicon (Hunter et al., 1993), allowing for discrimination between shales and lignite (e.g. Gormley, 2017). However, natural heterogeneity, both within and between deposits, has been highlighted as an issue when using XRF data to link carved materials to original source material (e.g. Penton, 2008; Brasser, 2015).

XRF was applied in this study to investigate the variation between the samples, and to determine its suitability for further studies. Due to a lack of suitable standard material the data are presented semi-quantitatively (Table 1) with the balance of each sample assumed to be carbon. Only elements with concentrations $>0.1 \%$ are included. Figure 9 presents several of the XRF spectra measured, demonstrating the variation observed between the cannel coal, the Pitch Lake crust, and the bird/monkey carving.

\begin{tabular}{lcccccc} 
& $\mathbf{F e}$ & $\mathbf{K}$ & $\mathbf{C a}$ & $\mathbf{S i}$ & $\mathbf{S}$ & $\mathbf{T i}$ \\
\hline Cannel coal & 0.21 & 0.00 & 0.22 & 0.69 & 1.73 & 0.06 \\
\hline Lignite & 0.24 & 0.07 & 0.35 & 5.40 & 20.52 & 0.02 \\
\hline Whitby jet & 0.89 & 0.46 & 0.15 & 2.20 & 13.70 & 1.88 \\
\hline Pitch Lake crust & 1.35 & 0.63 & 0.11 & 4.98 & 8.75 & 0.21 \\
\hline Trinidad beach & 0.11 & 0.06 & 0.01 & 0.59 & 11.47 & 0.01 \\
\hline Bird/monkey & 0.33 & 0.12 & 0.83 & 0.52 & 1.41 & 0.02
\end{tabular}


Table 1: Element concentrations as determined by benchtop XRF (all values as weight percent).

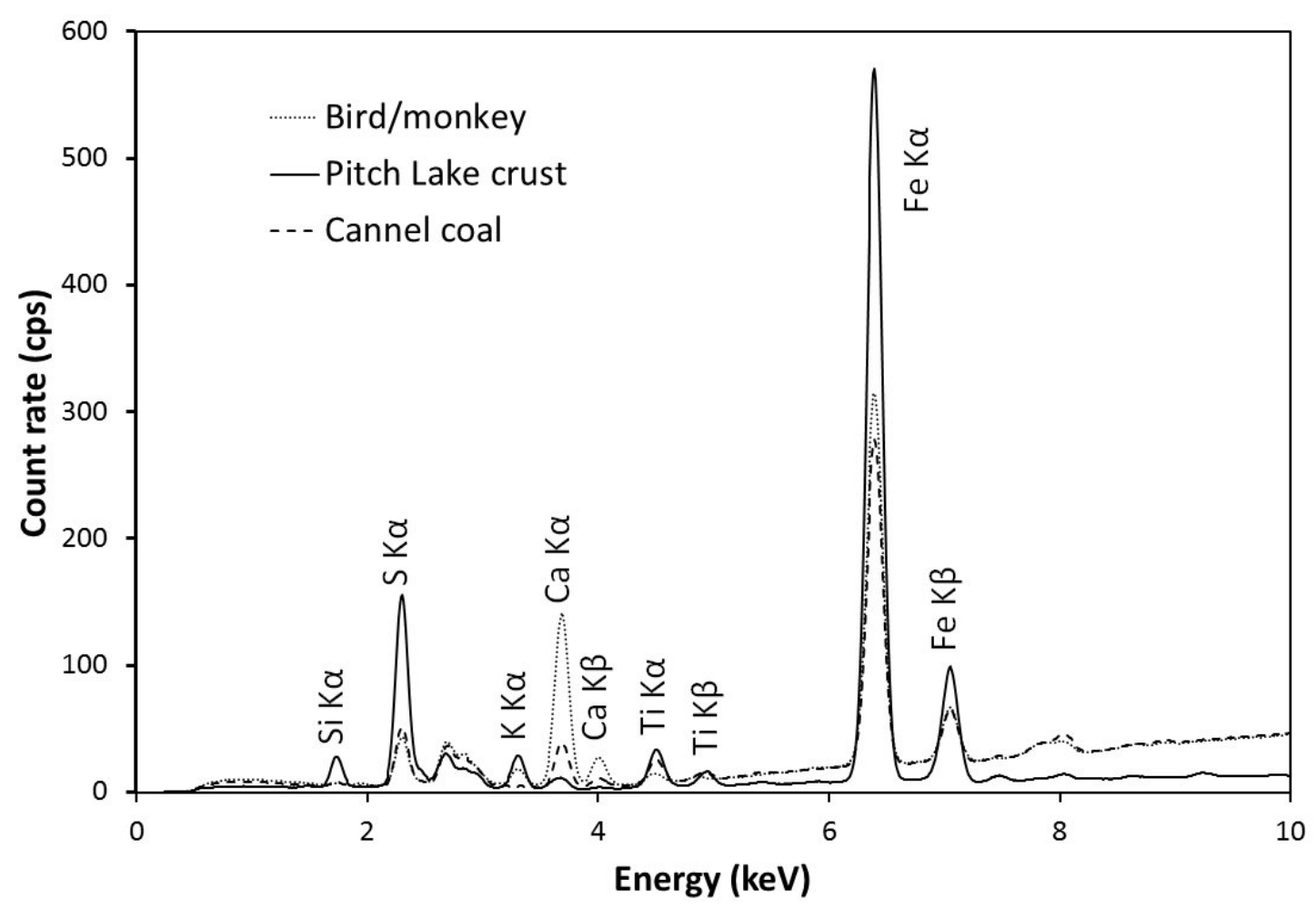

Figure 9: XRF spectra of the bird/monkey carving, the Pitch Lake crust sample, and the cannel coal sample, highlighting the differences in elemental concentration.

Other elements were detected in trace amounts as follows: Cannel coal: nickel, copper; Lignite: arsenic, tungsten, germanium; Jet: vanadium, chromium, copper, nickel; Pitch Lake crust: nickel, copper, rubidium; Beach: vanadium, nickel, copper; bird/monkey: copper; frog: copper.

Without a larger comparative dataset, it is difficult to draw a conclusion from the data, although some elements, such as copper and calcium, can be discarded immediately, having previously been found to be influenced by the burial environment of the artefact, rather than the original source material (Hunter et al., 1993). 
However, the greatest variation was observed for sulphur, which is known to be naturally present in petroleum-based materials. The cannel coal sample and the two carvings both contained significantly less sulphur $(<2 \%)$ than any of the other samples, although due to the aforementioned issues regarding sample heterogeneity, the data should be treated with caution when trying to identify the material type of either of the carved artefacts.

Variations were also observed for silicon, although at lower concentrations than sulphur, with concentrations highest for lignite and Pitch Lake crust material, and lowest for the cannel coal, beach material, and both carvings. Contrary to the findings of Pollard et al. (1981) and Hunter et al. (1993) that iron levels were lower in jet than other materials, the jet sample in this study had higher iron concentrations than all other samples, with the exception of the Pitch Lake crust.

\subsubsection{HH-XRF analysis}

Hand-held XRF is less sensitive than benchtop analysis, but was undertaken on the bird/monkey carving as a comparison to determine its suitability for analysis of artefacts without the need for destructive sampling.

Analysis of several spots on the bird/monkey carving detected a wide range of elements, including high counts for iron, sulphur, calcium, potassium and strontium, and low levels of aluminium, silicon, phosphorus, titanium, barium, copper, zinc, lead, rubidium, mercury and bromine (Fig. 10a,b). A small region of the same area of the artefact was then cleaned to remove any surface wax and other museum treatments, prior to re-analysis. The cleaning removed the mercury and bromine, and reduced the levels of lead, aluminium, phosphorus and calcium, the presence of which may be attributed to the application of pesticides to the museum collections (Charlton et al., 2014). 

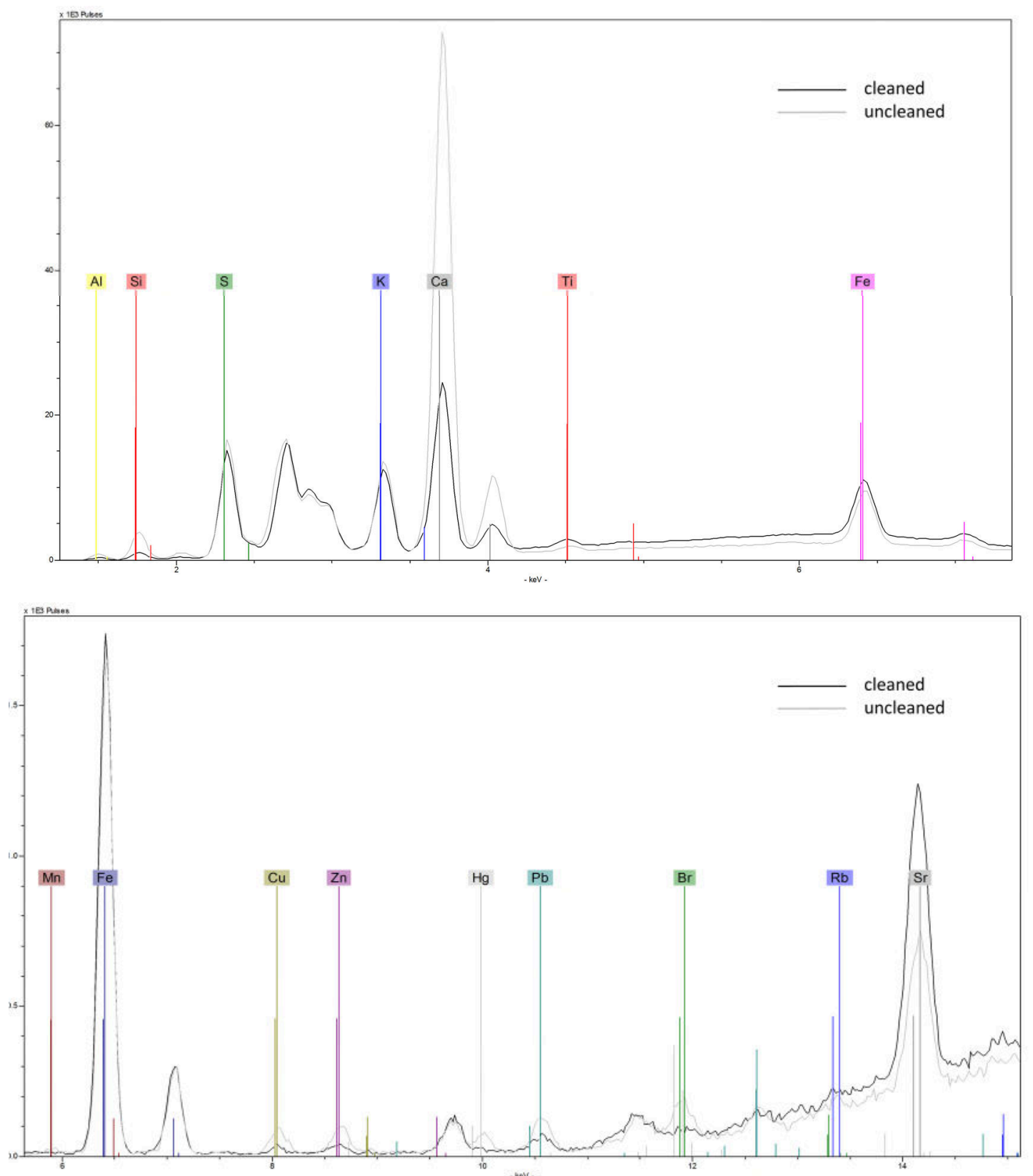

Figures 10a and b. Hand-held XRF spectra of cleaned and uncleaned areas of the bird/monkey carving highlighting the compositional differences between the surface and underlying material. [Images to be reproduced in colour]

This comparison of the two XRF techniques highlights the need for careful consideration of surface analysis where destructive analysis is not possible, as objects in collections may have either undergone conservation treatment themselves, or have been cross-contaminated, especially with 
pesticide residues from historic treatments within ethnographic collections worldwide.

\subsection{Composition and source of the bird/monkey and frog carving material}

Comparison of fragments from both the bird/monkey and frog carvings with the five comparative specimens show them to be most similar to cannel coal. Furthermore, comparison of the FTIR and py-GC/MS data for the carvings with published data for other specimens of cannel coal, lignite and jet (Watts and Pollard, 1998; Watts et al., 1999), also supports the conclusion that these two carvings are most likely made from cannel coal (or similar) and confirms that they are not made of lignite or jet. Although both carvings appear very similar, it is not possible to confirm whether they are from the same source material, especially due to the presence of museum conservation treatments on the bird/monkey snuff tube.

Visual observations and comparison of both sulphur concentration (as detected by XRF) and the FTIR spectra of the carvings with the solidified surface crust material from Pitch Lake, suggest that it is unlikely that the frog carving is made of either pitch or gutta percha, as recorded in the museum's notes accompanying the object.

If both carvings are, as the data imply, made of cannel coal, it is highly likely that the source material originated in mainland South America, most likely Venezuela or Colombia, due to the lack of any coal in the Caribbean island chain. There were quite active trade networks spanning the Lesser Antillean region during the Early Ceramic Period, between AD 200-800 (e.g. Hofman et al., 2007; Figures 6-7), encompassing eastern Puerto Rico south to Trinidad, the latter the main entrepôt through which South American materials (and people) migrated north along the island chain. Barrancoid materials - inclusive of ceremonial artefacts, such as the St Vincent bird/monkey snuff tube - are understood to have spread from the mainland through to Trinidad and Tobago, perhaps as far as the southern Leewards between AD 300 and 650/700 (e.g., ibid: 252). As far as currently known, the distribution of the anthropo-/zoomorphic carvings, which appear at both Huecan (La Hueca, Puerto Rico) and Saladoid (Escape, St Vincent) sites, spans St Vincent north to Puerto Rico. 


\subsection{Analytical strategy}

This study was undertaken to identify the most suitable techniques for identification of the carving material for similar Caribbean pre-Columbian carvings. The four complimentary analytical techniques applied here (reflectance microscopy, FTIR, py-GC/MS and XRF) were chosen to investigate the chemical composition and biological components of the samples based on previous studies of archaeological carvings in cannel coal, lignite and jet. FTIR and XRF were partly chosen due to the availability of hand-held instruments, which might allow for non-destructive analysis within museums and other collections in future studies.

All four techniques were informative, although the XRF data should be considered with caution based on sample heterogeneity within individual geological deposits. Both reflectance microscopy and py-GC/MS require destructive analysis, although this study demonstrated that they can both be applied to very small masses of sample. Reflectance microscopy can be undertaken on small samples, preferably with one dimension at least $2 \mathrm{~mm}$ thick to be readily embedded in resin and polished. The use of such small samples, however, reduces the available area on which to assess sample uniformity/variability. Powdered samples can also be studied using reflectance microscopy if necessary, but are more challenging and time-consuming to embed. Py-GC/MS requires only $\sim 0.1 \mathrm{mg}$ material for analysis.

Hand-held versions of FTIR and XRF are both available, which makes them appealing for analysis of samples on-site in museum collections, and for artefacts which cannot be sampled, but these portable instruments often lack the sensitivity of other techniques, and surface analysis has been shown in this study to be affected by the presence of museum conservation treatments. The benchtop FTIR utilised in this study required only 2-3 mg of material for analysis, which could usually be recovered afterwards and potentially submitted for py-GC/MS analysis.

If further analysis was to be undertaken on other similar Caribbean carvings, reflectance microscopy, py-GC/MS and FTIR should be considered together where destructive sampling is allowed, but undertaken alongside analysis of a considerably larger set of comparative geological specimens 
from across the region, including neighbouring mainland South America. Although the two carvings studied here were demonstrated to be most like the cannel coal sample, the possibility that similar carvings from the region may be made from less well-characterised materials, such as those associated with Pitch Lake, cannot be excluded. A larger comparative dataset would also improve understanding of sample heterogeneity, and enhance the potential for grouping samples from the same geological source together based on their biological and chemical components.

While XRF is not the most suitable stand-alone technique for identifying these black lithic materials, concentrations of sulphur, and possibly also silicon, are worthy of further investigation, especially where nondestructive analysis is required. However, care must be taken to ensure that the presence of museum conservation treatments does not influence the analytical data.

\section{Conclusions}

By comparison with specimens of cannel coal, lignite and jet, and two materials associated with Trinidad's Pitch Lake, as well as additional published data (e.g. Watts and Pollard, 1998; Watts et al., 1999) it is concluded that both the bird/monkey snuff tube and the frog carving found on the island of St Vincent are most likely to have been carved from cannel coal. Due to the lack of cannel coal deposits in the Caribbean islands, it is probable that these artefacts originated in mainland South America, possibly Venezuela or Colombia, and were traded northwards into the Lesser Antilles during the Early Ceramic Period. While it is currently not possible to conclude whether the two artefacts were carved from the same source material, the detailed interrogation of their structure is a critical first step in efforts to document the connections which linked communities within the insular Caribbean and neighbouring South America in an exchange of such ceremonial artefacts.

\section{Acknowledgements}

The Board of the St Vincent and Grenadines National Trust are thanked for permissions to sample and study the frog carving in their collections, with the invaluable support of Kathy Martin and La Verne Phillips, 
Collection Manager. The Pitt Rivers Museum, particularly Laura van Broekhoven, Jeremy Coote and Laura Peers are thanked for their permissions to include the bird/monkey snuff tube in the study.

Ostapkowicz's visit to the St Vincent museum was part of the Arts and Humanities Research Council funded project, "Black Pitch, Carved Histories" $(\mathrm{AH} / \mathrm{L00268X/1)}$. The authors thank the Natural Environment Research Council, UK, for partial funding of the mass spectrometry facilities at Bristol (contract no. R8/H10/63). Reflectance microscopy was undertaken in the Earth Sciences Department of Royal Holloway, University of London with the support of Neil Holloway (resin block preparation) and Sharon Gibbons (assistance with analysis). FTIR analysis was undertaken in the Centre for Defence Chemistry, Cranfield University, Defence Academy of the United Kingdom.

Paul Hackley (USGS) is thanked for supplying the specimen of Venezuelan cannel coal, and for helpful discussions about coal in the region. Alan Graham (Missouri Botanical Garden) and Manuel Iturralde-Vinent (academician emeritus, Cuban Academy of Sciences) are thanked for discussions about lignite and similar materials in the Caribbean, and Alex C. Wiedenhoeft (USDA Forest Service) for discussions about gutta percha and balata. 


\section{References}

Albuquerque, S. 2018. Objects, histories and encounters: British Guiana seen through balata. Fronteiras: Journal of Social, Technological and Environmental Science 7(1): 124-141.

Allason-Jones, L., Jones, J.M. 2001. Identification of 'jet' artefacts by reflected light microscopy. European Journal of Archaeology 4(2): 233-251.

Antczak, M.M., Antczak, A.T. 2006. Los idolos de las Isla Prometidas: Arqueología prehispánica del Archipíelago de Los Roques. Caracas: Equinoccio.

Antczak, M.M., Antczak, A.T. 2011. Their world in clay: The art of preHispanic Venezuela in: Ancient American Art 3500 BC - 1532. Masterworks of the Pre-Columbian Era. Milan: 5 Continents Editions, 173-204

Arroyo, M., Cruxent, J., Soto de Atencio, S. 1971. Arte Prehispanico de Venezuela, Caracas. Fundación Eugenio Mendoza.

Babalool, A.A., Littke, R., Wilson, B., Stock, A.T., Knight, J. 2016.

Petrographical and geochemical characterization of lignites, sub-bituminous coals and carbonaceous sediments from the Erin Formation, Southern Basin, Trinidad - Implications on microfacies, depositional environment and organic matter alteration. International Journal of Coal Geology 163: 112-122.

Baron, A., Gratuze, B. 2016. Application of LA-ICP-MS to black stone objects used during the Iron Age in Celtic Europe. In: Recent Advances in Laser Ablation ICP-MS for Archaeology. Eds Dussubieux L, Golitko M, Gratuze B. Natural Science in Archaeology Series. Springer-Verlag Berlin Heidelberg.

Boomert, A., 2016. The indigenous peoples of Trinidad and Tobago: From the first settlers until Today. Sidestone Press, Leiden. 
Brasser, J.P. 2015. Jet artifacts from two Neolithic sites on the Dutch coast: An experimental approach. MSc thesis, Leiden University.

Brock, F., Ostapkowicz, J., Wiedenhoeft, A.C., Bull, I.D. 2017. Radiocarbon dating wooden carvings and skeletal remains from Pitch Lake, Trinidad. Radiocarbon 59(5): 1447-1461.

Chanlatte Baik, L., Narganes Storde, Y. 1984. Arqueología de Vieques, Second Edition, Centro de Investigaciones Arqueológicas, Universidad de Puerto Rico, Río Piedras, Editorial Corripio, C., Santo Domingo.

Charlton, A., Domoney, K., Uden, J. 2014. Pesticide residues on the Cookvoyage collections at the Pitt Rivers Museum, University of Oxford. ICOM-CC $17^{\text {th }}$ Triennial Conference Preprints, Melbourne, 15-19 September 2014. Ed. J Bridgland. Paris: International Council of Museums.

Clouth, F. 1903. Rubber, gutta-percha and balata. English Edition: McLaren \& Sons, London.

Collinson, M.E., Steart, D., Scott, A.C., Glasspool, I., Hooker, J.J. 2007. Episodic fire, runoff and deposition at the Paleocene-Eocene boundary. Journal of the Geological Society of London 164: 87-97.

Etrich, C. 2002. « Deviation de Capesterre Belle-Eau, Allée Dumanoir » Bilan Scientifique de la region Guadeloupe pp. 23-28.

Etrich, C. (ed.) 2003. Le Site de "l'Allée Dumanoir". INRAP report 971070045 $\mathrm{AH}$ prepared for the Conseil Régional de la Guadeloupe. Basse-Terre. (with contributions from P. Bertran, G. Chancerel, P. Fouéré, F. Honoré and Chr. Stouvenot.)

Falci, C.G. 2015. Stringing beads together: A microwear study of bodily ornaments in late pre-Colonial north-central Venezuela and north-western Dominican Republic. University of Leiden MSc thesis. 
Falci, C.G., Antczak, M.M., Antczak, A.T., van Gijn, A. 2017.

Recontextualizing bodily ornaments from North-Central Venezuela (AD 9001500): The Alfredo Jahn collection at the Ethnologisches Museum Berlin. Baessler-Archiv, Band 64 pp. 87-112.

Gormley, S. 2017. 'Lignite bracelet' production in the north of Ireland: a reassessment. The Journal of Irish Archaeology 26: 117-141.

Gutierrez Blanco, C., González Azpíroz, M.D., Fernández Valdés, A. 2008. Relationship between the working quality of Asturian jets (Spain) and their structure using parameters defined by ${ }^{1} \mathrm{H}-\mathrm{NMR}$. Archaeometry 50(5): 877886.

Graham, A. 1996. Paleobotany of Puerto Rico. From Arthur Hollick's (1928) Scientific Survey Paper to the Present. Annals of the New York Academy of Sciences 776(1): 103-114.

Hackley, P.C., Warwick, P.D., González, E. 2005. Petrology, mineralogy and geochemistry of mined coals, western Venezuela. International Journal of Coal Geology 63: 68-97.

Hicks, D., Cooper, J. 2013. The Caribbean. In: World Archaeology at the Pitt Rivers Museum: a characterization. D. Hicks and A. Stephenson eds., pp. 401-408, Archaeopress, Oxford.

Hofman, C.L., Bright, A.J., Boomert, A., Knippenberg, S. 2007. Island rhythms: The web of social relationships and interaction networks in the Less Antillean archipelago between 400 B.C. and A.D. 1492. Latin American Antiquity 18(3): 243-268.

Hunter, F.J., McDonnell, J.G., Pollard, A.M., Morris, C.R., Rowlands, C.C. 1993. The scientific identification of archaeological jet-like artefacts. Archaeometry 35(1): 69-89. 
Hudspith, V., Scott, A.C., Collinson, M.E., Pronina, N., Beeley, T. 2011.

Evaluating the extent to which wildfire history can be interpreted from inertinite distribution in coal pillars: An example from the Late Permian, Kuznetsk Basin, Russia. International Journal of Coal Geology 89: 13-25.

Iglesias, M.J., Jiménez, A., Laggoun-Défarge, F., Suárez-Ruiz, I. 1995. FTIR of pure vitrains and associated coals. Energy and Fuels 9: 458-66.

Iturralde-Vinent, M., Hartstein, E. 1998. Miocene amber and lignitic deposits in Puerto Rico. Caribbean J. of Science 34(3-4): 308-312.

Iturralde-Vinent, M. 2001. Geology of the amber-bearing deposits of the Greater Antilles. Caribbean J. Science. 37: 141-167.

Kalkan, E., Bilici, Ö., Kolayli, H. 2012. Evaluation of Turkish black amber: A case study of Oltu (Erzurum), NE Turkey. Int. J. of Physical Sciences 7(15): 2387-2397.

Kalkreuth, W., Sutherland, P.D. 1998. The archaeology and petrology of coal artifacts from a Thule settlement on Axel Heiberg Island, Arctic Canada. Arctic 51(4): 345-349.

Kalkreuth, W., Andreasen, C., Petersen, H.I., Stemmerik, L. 2012. The petrology and provenance of coal artifacts from Thule settlements in northeastern Greenland. Bulletin of the Geological Society of Denmark

Kidder, A. 1944. Archaeology of Northwestern Venezuela, PMAE, Harvard, vol XXVI (1).

Kool, J., Poole, I., van Bergen, P.F. 2009. How jet is formed: An organic geochemical approach using pyrolysis gas chromatography-mass spectrometry. Organic Geochemistry 40: 700-705. 
Lambert, J.B., Frye, J.S., Jurkiewicz, A. 1992. The provenance and coal rank of jet by carbon-13 nuclear magnetic resonance spectroscopy. Archaeometry 34: 131-8.

Larter, S. R. (1984). Application of analytical pyrolysis techniques to kerogen characterization and fossil fuel exploration/exploitation. In (K. J. Voorhees, Ed.) Analytical Pyrolysis: Techniques and Applications. London: Butterworths, pp. 212-275.

Monnier, G.F. 2018. A review of infrared spectroscopy in microarchaeology: Methods, applications, and recent trends. Journal of Archaeological Science: Reports. 18: 806-823.

Muller, H. 1980. Jet jewellery and ornaments. Shire Publications Ltd, Aylesbury, UK.

Muller, H., Muller, K. 2009. Whitby jet. Shire Publications, Oxford, UK.

Noorbergen, L.J., Abels, H.A., Hilgen, F.J., Robson, B.E., De Jong, E., Dekkers, M.J., Krijgsman, W., Smit, J., Collinson, M.E., Kuiper, K.F. 2018. Conceptual models for short-eccentricity-scale climate control on peat formation in a lower Palaeocene fluvial system, north-eastern Montana (USA). Sedimentology 65: 775-808.

Orndorff, R.C. 1985. Annotated bibliography of coal in the Caribbean Region. UGSG open-file report 85-110.

Ostapkowicz, J., Bronk Ramsey, C., Brock, F., Higham, T., Wiedenhoeft, A.C., Ribechini, E., Lucejko, J.J., Wilson, S. 2012. Chronologies in wood and resin: AMS ${ }^{14} \mathrm{C}$ dating of pre-Hispanic Caribbean wood sculpture. Journal of Archaeological Science 39: 2238-2251.

Ostapkowicz, J., Bronk Ramsey, C., Brock, F., Cartwright, C., Stacey, R., Richards, M. 2013. Birdmen, cemís and duhos: material studies and AMS ${ }^{14} \mathrm{C}$ 
dating of Pre-Hispanic Caribbean wood sculptures in the British Museum. Journal of Archaeological Science 40: 4675-4687.

Ostapkowicz, J. 2016. Étude sur les figurines en «Bois». Bilan Scientifique: Direction Régionale des Affaires Culturelles Guadeloupe pp. 58-61.

Ostapkowicz, J., in press. Conduits to the supernatural: Composite snuff tubes in the pre-Columbian Caribbean. Submitted to Journal of Caribbean Archaeology.

Penton, S. 2008. Cumwhitton, Cumbria: Analytical investigation of jet-like objects from a Viking cemetery. English Heritage Research Department Report Series no. 18/2008.

Peters, K.E., Walter, C.C., Moldowan, J.M. 2005. The Biomarker Guide Volume 2: Biomarkers and Isotopes in Petroleum Exploration in Earth History. Cambridge University Press, Cambridge, United Kingdom, 1155pp.

Petit Roget 1995. « Note sur deux amulettes de bois trouvées à Morel, Guadeloupe » in International Congress of Caribbean Archaeology, pp. 417422. San Juan Puerto Rico.

Pollard, A.M., Bussell, G.D., Baird, D.C. 1981. The analytical investigation of Early Bronze Age jet and jet-like material from the Devizes Museum. Archaeometry 23: 139-67.

Prakesh, R., Gopikrishna, V., Kandaswamy, D. 2005. Gutta-percha - an untold story. Endodontology 17(2):32-35

Rainey, F. 1940: Scientific survey of Porto Rico and the Virgin Islands, The New York Academy of Sciences, vol. XVIII (1), New York.

Robson, B.E., Collinson, M.E., Riegel, W., Wilde, V., Scott, A.C., Pancost, R.D. 2015. Early Paleogene wildfires in peat-forming environments at 
Schöningen, Germany. Palaeogeography, Palaeoclimatology, Palaeoecology, 438: 53-62.

Sales, K.D., Oduwole, A.D., Convert, J., Robins, G.V. 1987. Identification of jet and related black materials with ESR spectroscopy. Archaeometry 29: 1039.

Sealey, N.E. 1986. Natural Resources in the Caribbean. Hodder and Stoughton.

Sheridan, J.A., Davis, M., Clark, I., Redvers-Jones, H. 2002. Investigating jet and jet-like artefacts from prehistoric Scotland: the National Museums of Scotland project. Antiquity 76: 812-825.

Sheridan, J.A. 2015. Discussion of disc bead and spacer plate necklaces of jet and jet-like materials. In: Woodward, A., Hunter, J. (Eds.), Ritual in Early Bronze Age Grave Goods. Oxbow Books, Oxford, pp. 341-62.

Sheridan, J.A. 2017. Towards a methodology for the study of prehistoric jet and jet-like jewellery. In: Shaffrey, R. (Ed.), Written in stone: papers on the function, forms, and provenancing of prehistoric stone objects in memory of Fiona Roe. Southampton Monographs in Archaeology, St Andrews: Highfield Press, pp. 249-74.

Spinden, H.J. 1916. New data on the archaeology of Venezuela. PNAS 2(6): 325-328.

Stach, E., Mackowsky, M.-Th., Teichmüller, M., Taylor, G.H., Chandra, D., Teichmüller, R. 1982. Stach's Textbook of Coal Petrology, $3^{\text {rd }}$ Edition. Berlin and Stuttgart: Borntraeger.

Steart, D.C., Collinson, M.E., Scott, A.C., Glasspool, I.J., Hooker, J. 2007. The Cobham Lignite Bed: the palaeobotany of two petrographically 
contrasting lignites from either side of the Paleocene-Eocene carbon isotope excursion. Acta Palaeobotanica 47: 109-125.

Suárez-Ruiz, I., Flores, D., Filho, J.G.M., Hackley, P.C. 2012. Review and update of the applications of organic petrology: Part 2, geological and multidisciplinary applications. International Journal of Coal Geology 98: 73-94.

Suárez-Ruiz, I., Iglesia, M.J. 2007. Spanish jet: Something more than a gemstone with magical properties. Energeia 18(1): 1-3.

Teichmüller, M. 1992. Organic petrology in the service of archaeology. Int. J. Coal Geology 20(1-2): 1-21.

Traverse, A., Kolvoord, R.W. 1968. Utah jet: a vitrinite with aberrant properties. Science 159: 302-5.

Waldron, L. 2016. Handbook of ceramic animal symbols in the ancient Lesser Antilles. University of Florida Press, Gainesville.

Watts, S., Pollard, A.M, Wolff, G.A. 1997. Kimmeridge Jet - a potential new source for British jet. Archaeometry 39(1): 125-143.

Watts, S, Pollard, A.M. 1998. Identifying archaeological jet and jet-like artifacts using FTIR. IRUG 2 Postprints 37-52.

Watts, S., Pollard, A.M., Wolff, G.A. 1999. The organic geochemistry of jet: pyrolysis-gas chromatography/mass spectrometry (Py-GC/MS) applied to identifying jet and similar black lithic materials - preliminary results. Journal of Archaeological Science 26: 923-933.

Woodward, A., Hunter, J. 2015. Ritual in Early Bronze Age Grave Goods. Oxbow Books, Oxford. 